som ønsker å hjelpe pasientene til atferdsendring, vil finne bedre og mer kortfattet innføring andre steder.

Ivar Sønbø Kristiansen

Institutt for helseledelse og helseøkonomi Universitetet i Oslo

\section{Enda mer kunnskap om det samme}

Adrianne E. Hardman, David J. Stensel Physical activity and health

The evidence explained. $340 \mathrm{~s}$, tab, ill.

Oxon: Routledge, 2009. Pris GBP 35

ISBN 978-0-415-42198-0

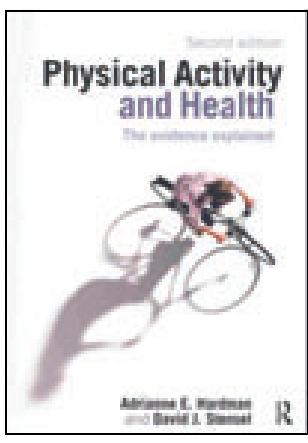

Fysisk aktivitet fremmer god helse og forebygger mange syk-

dommer, særlig vår tids store folkesykdommer. Trenger du å lese en hel bok med grundig vitenskapelig dokumentasjon for å godta denne

påstanden? Eller holder det med ovenstående setning?

Vi er kanskje forskjellig skrudd sammen. Noen av oss føler behov for å lese nok en bok for å være helt trygge på at det er helt sikkert at fysisk aktivitet er et nyttig hjelpemiddel - både for å forebygge og behandle de store folkesykdommene. For dem vil jeg anbefale Physical activity and health fordi den er lettlest og har søkelyset rettet mot tilstander der fysisk aktivitet virkelig gjør forskjell: diabetes, fedme, kardiovaskulære sykdommer, metabolsk syndrom, osteoporose, barn og aldring. Rygglidelser og psykisk sykdom glimrer forresten med sitt fravær. Du kan faktisk ikke være i tvil om nytten av fysisk aktivitet etter å ha lest deg gjennom disse kapitlene som buler av oppdaterte forskningsresultater - bare kildehenvisningene fyller 38 sider, altså over $10 \%$ av boken. Det man derimot kan undres på, er hva som er galt med forskningen som beviser det samme om igjen og om igjen, i stedet for å ta neste skritt: å lete etter praktisk bruk av det vi nå vet så altfor godt, og ikke trenger flere forskningsresultater på.

For oss som lever i en hverdag fylt av ørevoks og andre banaliteter, gir forfatterne en flott repetisjon i faget epidemiologi og hvordan man skal tolke forskningsresultater. Forfatterne gir også en god innføring i oppdatert viten om de ovennevnte sykdomsgruppene.

Spørsmålet er bare om vi skal bruke tid på å lese dette. Burde vi ikke snart komme oss et skritt videre og finne ut hvordan vi får befolkingen til å bedrive mer fysisk aktivitet - siden det er så helsebringende. Denne problemstillingen tar forfatterne ikke fatt i, og det har nok heller aldri vært intensjonen. Det er synd, for det er jo her det begynner å bli spennende.

Selv om boken er godt skrevet og har en lekker layout, vil jeg foreslå at potensielle lesere prioriterer tid, penger og leselyst på noe annet. Kom deg ut i marka og forebygg sykdom i egen kropp mens du grubler på hva som skal til for å sette forskningsresultatene ut i praksis!

\section{Jannike Reymert}

Bakklandet legekontor

Namsos

\section{Utmerket om idrettskardiologi}

Greg Whyte, Sanjay Sharma

Practical ECG for exercise science and sports medicine

167 s, tab, ill. Leeds: Human Kinetics, 2010 Pris GBP 22

ISBN 978-0-7360-8194-8

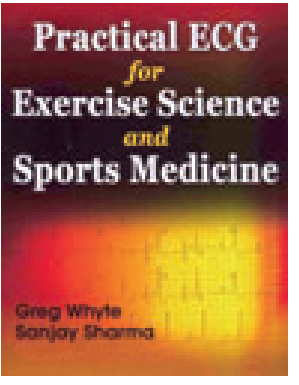

En sjelden gang skjer det sjokkerende: En idrettsutøver faller livløs om, iblant med «hele verden» som TV-tilskuer. De senere årene er man blitt mer oppmerksom på at selv om idrett er sunt

for de fleste, kan det være farlig for noen få. EKG hos toppidrettsutøvere kan ha bisarre forandringer. Hva er normal hjertefysiologi hos dem som trener mye? Hvordan skal en lege vurdere «patologiske» EKG-forandringer hos en tilsynelatende supersprek person? Hva med screening av utøvere en til dels opphetet debatt i mange land og med ulike løsninger? Bred interesse for mosjon, og ganske hard trening også blant eldre mosjonister, har dessuten gjort det viktig å differensiere normale og patologiske forandringer i hjertet som følge av intens trening.

Whyte og Sharma har skrevet en grundig, men lettlest bok om idretts-EKG. Begge forfatterne er internasjonalt meget kjente og har involvert seg i Cardiac Risk in the Young, en frivillig organisasjon som har nedlagt et stort arbeid for å redusere antall unge hjertedøde (1). Whyte er dessuten tidligere toppidrettsutøver. Sharma er sentral innen idrettskardiologi i European Society of Cardiology (2).

Boken er nærmest et kompendium, rikelig illustrert og tydelig med nøkkelpunkter. Den er basal og enkel, samtidig som den er avansert med komplekse problemstillinger. Boken er velegnet for flere som arbeider med fysisk trening og sport, men spesielt verdifull for indremedisinere, allmennleger og kardiologer. Særlig godt didaktisk er beskrivelsene av hjertets anatomi, elektrofysiologi og EKG-funn knyttet sammen.

I del 1 tar forfatterne for seg hjertets struktur, funksjon og anatomi, hjertets elektriske egenskaper, aksjonspotensialer, ledningssystemet, autonom regulering og kontraksjonsmønstre. De beskriver EKG i hvile og under aktivitet, og vanlige belastningsprotokoller.

Del 2 handler om normalt og unormalt hvile-EKG; rytme, intervaller, akser, morfologi, identifisering av forstørrede atrier og ventrikler, iskemi, brady- og takyarytmier, aksessoriske ledningsveier, kanalopatier, perimyokarditt, hypertrofisk kardiomyopati, elektrolyttforstyrrelser og medikamenteffekter. Forfatterne beskriver både normalfysiologiske og patologiske forandringer som kan opptre under trening, likeledes normalt og patologisk belastnings-EKG.

I del 3 beskriver forfatterne spesifikt idrettshjertet: Hva er fysiologiske forandringer? Hva er patologiske forandringer? Hjertets struktur og systoliske og diastoliske funksjon hos toppidrettsutøvere beskrives, med avgrensning av tillatt masseøkning, veggtykkelser og kammerdiameter hos begge kjønn. Kraftig økt vagustonus kan gi bradyarytmi, som hos utrente er patologi, men hos idrettsutøvere normalt. Synkope hos en idrettsutøver er alltid et varsel, og utredning er påkrevet. Forfatterne omtaler forekomsten av plutselig død i idrett og gjør det klart at de støtter idrettsscreening etter den europeiske modellen; enkel klinisk undersøkelse, egenanamnese og slektsanamnese og et 12-kanal-EKG

Boken avsluttes med seks svært interessante og lærerike kasuistikker.

\section{Erik Ekker Solberg}

Seksjon for hjertesykdommer

Diakonhjemmet Sykehus

\section{Anders Nesvold}

Hjertemedisinsk avdeling

Oslo universitetssykehus, Ullevål

\section{Litteratur}

1. Cardiac risk in the young. www.c-r-y.org.uk (11.3.2011)

2. Sports cardiology section. European Society of Cardiology www.sportscardiology.eu (11.3.2011). 